\title{
The Turnover of Cholesterol in Human
}

\section{Atherosclerotic Arteries}

\author{
S. N. Jagannathan, W. E. Connor, W. H. Baker, and \\ A. K. Bhattacharyya \\ From the Clinical Research Center, and the Departments of Internal Medicine \\ and Surgery, University of Iowa College of Medicine, Iowa City, Iowa 52242
}

A в S T R A C T The equilibration of cholesterol between plasma and atherosclerotic arteries was studied in 13 patients with obstructive atherosclerosis 2-96 days after the intravenous and/or oral administration of isotopic cholesterol. Arterial specimens were obtained in 12 patients during surgery for arterial reconstruction and in a 13th patient at autopsy. Equilibration was calculated as the specific radioactivity of cholesterol in the arterial tissue relative to that in the plasma (percent).

In specimens obtained 2-4 days after pulse labeling, the specific activity of cholesterol in atheroma ranged from 0.3 to $4.5 \%$ of that in the plasma. By $17-27$ days, the relative specific activity ranged from 6 to $20 \%$ in different arteries. In contrast, cholesterol of skeletal muscle had a relative specific activity of $96 \%$ by 22 days. By 61-96 days, atheroma cholesterol in the abdominal aorta, common iliac, and femoral arteries had equilibrated to 55,30 , and $26 \%$, respectively. In the patient who died at 96 days, the cholesterol in the coronary arteries had a mean equilibration of $66 \%$, similar to the values for the abdominal (66\%) and thoracic (57\%) aortas. The route of administration of the isotope did not influence the equilibration.

Within the atheromatous plaque, the superficial layers equilibrated better than the deeper layers ( $75 \%$ vs. $22 \%$ ). The free cholesterol in the atheroma equilibrated to a significantly higher extent than did esterified cholesterol ( $59 \%$ vs. $38 \%$ ). There was a fourfold higher specific activity of cholesterol in the media than in the corresponding intima (916 vs. $230 \mathrm{dpm} / \mathrm{mg}$ ).

The estimated minimal influx rates of plasma cholesterol into the atheromatous intima ranged from 0.065

This work was presented in part at the 26th Annual Meeting of the Council on Arteriosclerosis, American Heart Association, Dallas, Texas, 18 November 1972 and has been published as an abstract (1).

Received for publication 12 February 1974 and in revised form 15 April 1974. to $0.274 \mathrm{mg}$ of cholesterol/g dry tissue per day for different arteries. The approximated turnover times of atheroma cholesterol ranged from 442 days for the abdominal aorta and the coronary arteries to 580 days for the common iliac and 821 and 934 days, respectively, for the femoral and the carotid arteries.

These data indicate a definite, though slow, exchange of cholesterol between the plasma and severely atherosclerotic human arteries. Within the atheroma, there are multiple pools of cholesterol, each turning over differently and more slowly than the cholesterol of most other tissues, such as the skeletal muscle. The estimates of influx rate and turnover time of atheroma cholesterol suggest the possibility that this cholesterol is mobilizable, an indication of potential regression of atheromatous lesions in man.

\section{INTRODUCTION}

Previous radioisotopic exchange studies in patients with limited life expectancy have indicated that the tracer cholesterol fed orally or administered intravenously could be detected in the aorta and other arteries at autopsy (2-7). Since the labeled cholesterol was incorporated into the plasma lipoproteins after its administration $(2,8)$, these results demonstrated a measure of equilibration of cholesterol between plasma and arterial tissues. In these patients with terminal disease and generally poor nutritional state, steady-state conditions did not usually prevail, and cholesterol turnover in the atheromatous lesions could not be reliably estimated. It would thus be desirable to study the equilibration of cholesterol between the plasma and arteries in living humans, without the complication of debilitative terminal illnesses, and during a period of time when the subjects were in a metabolic steady state. Such a study could provide information about the rate of influx of plasma cholesterol into atheromatous arteries and whether the influx rate is different in different arteries, 
in different lesions, and in different layers of the atheromatous plaque.

Further, it is not known whether cholesterol, once it is deposited in the arterial intima, is mobilizable thereafter, thus indicating the possibility of regression of the atheromatous lesions. Experiments on the rhesus monkey have proved that regression of severe atherosclerotic lesions can occur (9), but in man, this problem can never be investigated by such direct means. In the present investigation, isotope exchange studies have been used to estimate the minimal influx rates of plasma cholesterol into severely atherosclerotic plaques in patients in a metabolic steady state. The rates have in turn been utilized to derive the maximal estimates for turnover time of atheroma cholesterol in order to ascertain the possibility of regression of established atherosclerotic lesions in man.

\section{METHODS}

Subjects. 13 patients who had progressive obstructive atherosclerosis, 9 men and 4 women, aged 40-69 yr, were the subjects of this investigation (Table I). Six patients had serum lipid values classifiable as type II-a hyperlipoproteinemia; one patient had the Type II-b pattern; four showed the type IV pattern; and two others had serum lipid levels usually considered normal $(10,11)$. The mean serum lipid levels for the whole group of patients were: cholesterol, $255 \pm 72$ (SD) and triglycerides, $191 \pm 83 \mathrm{mg} / 100$ ml. 12 of the patients (nos. 1-12) had severe peripheral atherosclerosis and had a history of moderate to heavy smoking over a period of 2 decades or more. They had been referred for elective surgical reconstruction of peripheral arterial stenosis. The remaining patient (no. 13), a nonsmoker, had severe coronary stenosis (three vessel disease) and was not a candidate for bypass surgery. This man had a fatal cardiac arrest in the hospital from an acute myocardial infarction. One patient, (no. 8) was receiving cholestyramine (Questran, Mead Johnson Laboratories, Evansville, Ind., $16 \mathrm{~g} / \mathrm{day}$ ) and clofibrate (Atromid$\mathrm{S}$, Ayerst Laboratories, New York, $2 \mathrm{~g} /$ day). Another patient (no. 12) had juvenile-onset diabetes, well controlled by insulin. These medications were continued at the same level throughout the period of the study. Other patients were not receiving hypocholesterolemic agents. Informed consent was obtained from each subject according to the Declaration of Helsinki.

Diets. During the period of study, all the patients received eucaloric diets similar to their home diets with respect to the quantity and type of fat and the amount of cholesterol. Six of the patients (nos. 8-13) had received special dietary advice earlier. Five of these (nos. 8-12) had diets providing $20 \%$ fat calories (iodine, no. 80-85) and a cholesterol content of $100 \mathrm{mg}$ for periods of a few months to 1 year before their enrollment in the study. Patient 13 had been given a cholesterol-free diet with $40 \%$ of the calories from fat with an iodine number of 120 . The remaining patients had been consuming a general American diet, providing $30-40 \%$ of calories as fat with a cholesterol content of about $500-600 \mathrm{mg} /$ day. During the period of the study, all the subjects were in a metabolic steady state. ${ }^{1}$

Experimental plan. Each patient was given radio-labeled cholesterol at varying periods of time before the surgical reconstruction of the peripheral arteries. The specific radioactivity (sp act) of the plasma cholesterol was followed periodically until the day of surgery. Specimens of obstructed arteries were obtained at surgery and analyzed for cholesterol content and specific radioactivity.

Isotopic cholesterol ${ }^{2}$ was administered either intravenously or orally; in some patients, both routes of administration were utilized. Before use, the purity of the isotopes was verified (97\% recovery) by thin-layer chromatography (on silica gel $\mathrm{G}$ in a solvent system of benzene: ethyl acetate, 9:1). For intravenous administration, isotopic cholesterol was dissolved in $5 \mathrm{ml}$ of ethanol, sterilized by passing through a $0.2-\mu$ millipore filter, and diluted in $500 \mathrm{ml}$ of sterile normal saline. This solution was infused intravenously over a $1-\mathrm{h}$ period. 11 of the patients received the isotope by the intravenous route; 2 patients received the isotope only through the oral route; and 5 patients were given 2 different isotopes of cholesterol orally and intrevenously (Table I). The oral administration was in the form of a breakfast meal previously described (12) and contained the labeled cholesterol mixed with egg yolk to provide $500 \mathrm{mg}$ of cholesterol. One patient (no. 5) received separately both tritiated cholesterol and the $\left[\mathrm{C}^{\mathbf{1 4}}\right]$ cholesterol as intravenous infusions but at two different times, 17 and 62 days, respectively, before the day of surgery.

Collection of arterial specimens. Patients 1-12 underwent surgery for arterial reconstruction 2-81 days after receiving the labeled cholesterol (Table I). Endarterectomy or plaquectomy was performed in the carotid, femoral, and iliac arteries and the distal abdominal aorta. Some patients needed an aorto-femoral bypass grafting, in which case the obstructed arteries (mostly the distal aorta and the common iliac arteries) were excised, and the entire specimen was collected for analysis. Patient 13, who had severe three vessel coronary heart disease and who was being followed under a different protocol to study plasma cholesterol turnover, had a fatal cardiac arrest from an acute myocardial infarction 96 days after receiving isotopic cholesterol. At autopsy, in addition to specimens of the aorta and the three coronary arteries, tissues such as liver and skeletal muscle were also sampled for analysis. The arterial specimens removed at surgery were all severely atheromatous and had no areas of "normal" intima discernible by visual examination. Many plaques were ulcerated and calcified. Atheromatous abscesses, as well as obstructing thrombi, occurred frequently. Histological confirmation of the gross examination was obtained in all instances. A total of 43 arterial specimens were obtained from the 13 patients at different time periods (2-96 days) after administration of isotopic cholesterol.

Determination of specific activity of plasma cholesterol. The plasma cholesterol concentration was determined by the method of Abell, Levy, Brodie, and Kendall (13). Radioactivity was determined in the unsaponifiable extract of the plasma by using $10 \mathrm{ml}$ of a scintillation solution ( $4 \mathrm{~g}$ of

\footnotetext{
${ }^{1}$ The metabolic steady state is arbitrarily defined in this study as a state of constant plasma cholesterol level and body weight with a constant diet and stable clinical state throughout the observation period.

${ }^{2}\left[4-\mathrm{C}^{14}\right]$ Cholesterol (sp act, $59.8 \mathrm{mCi} / \mathrm{mmol}$ ) and $[1,2,-$ $\mathrm{H}^{3}$ ] cholesterol (sp act, $39 \mathrm{Ci} / \mathrm{mmol}$ ), obtained from the
} New England Nuclear Corp., Boston, Mass.

Turnover of Atheroma Cholesterol in Man 
TABLE I

The Clinical Description of the Subjects, the Isotopes Administered, and Arterial Specimens Analyzed

\begin{tabular}{|c|c|c|c|c|c|c|c|c|c|c|c|}
\hline \multicolumn{2}{|c|}{ Patient } & \multirow[b]{2}{*}{ Sex } & \multirow[b]{2}{*}{ Age } & \multirow[b]{2}{*}{$\begin{array}{l}\text { Body } \\
\text { wt }\end{array}$} & \multicolumn{2}{|c|}{ Serum lipids } & \multirow{2}{*}{$\begin{array}{l}\text { Classification } \\
\text { of hyperlipo- } \\
\text { proteinemia }\end{array}$} & \multicolumn{2}{|c|}{$\begin{array}{l}\text { Isotopic cholesterol } \\
\text { administered }\end{array}$} & \multirow{2}{*}{$\begin{array}{c}\text { Days } \\
\text { after } \\
\text { isotope }\end{array}$} & \multirow[b]{2}{*}{$\begin{array}{l}\text { Arterial specimens } \\
\text { analyzed }\end{array}$} \\
\hline No. & Initials & & & & $\begin{array}{l}\text { Choles- } \\
\text { terol }\end{array}$ & $\begin{array}{l}\text { Triglyc- } \\
\text { erides }\end{array}$ & & i.v. & Oral & & \\
\hline & & & $y r$ & $\mathrm{~kg}$ & \multicolumn{2}{|c|}{$\mathrm{mg} / 100 \mathrm{ml}$} & & \multicolumn{2}{|c|}{$\mu C i$} & & \\
\hline 1 & D. $\mathrm{M}$. & $\mathbf{M}$ & 66 & 93 & 335 & 186 & Type II-a & $90.5^{*}$ & & 4 & $\begin{array}{l}\text { Abdominal aorta } \\
\text { Common iliac }\end{array}$ \\
\hline 2 & J.S. & $\mathbf{M}$ & 57 & 85 & 196 & 88 & Normal & 99.0* & & 4 & Common iliac \\
\hline 3 & E. G. & $\mathbf{M}$ & 54 & 80 & 251 & 135 & $\begin{array}{c}\text { Type IIa } \\
\text { (mild) }\end{array}$ & 91.0* & & 7 & Femoral \\
\hline 4 & H. M. & F & 69 & 54 & 173 & 122 & Normal & $46.9 *$ & & $\begin{array}{r}2 \\
12\end{array}$ & $\begin{array}{l}\text { Carotid } \\
\text { Abdominal aorta }\end{array}$ \\
\hline 5 & N. B. & F & 50 & 63 & 265 & 232 & Type II-b & $\begin{array}{l}242 \ddagger \\
85.5^{*}\end{array}$ & & $\begin{array}{l}17 \\
62\end{array}$ & $\begin{array}{l}\text { Abdominal aorta } \\
\text { Common iliac }\end{array}$ \\
\hline 6 & C. w. & $\mathbf{M}$ & 60 & 92 & 220 & 351 & Type IV & & $137 \ddagger$ & 22 & Femoral \\
\hline 7 & C. $\mathrm{H}$. & $\mathbf{M}$ & 61 & 68 & 244 & 113 & $\begin{array}{l}\text { Type II-a } \\
\text { (mild) }\end{array}$ & & $221 \ddagger$ & 27 & $\begin{array}{l}\text { Abdominal aorta } \\
\text { Common iliac } \\
\text { Femoral }\end{array}$ \\
\hline 8 & C. B. & $\mathbf{M}$ & 47 & 76 & 221 & 245 & Type IV & $86.0^{*}$ & $284 \ddagger$ & 61 & $\begin{array}{l}\text { Abdominal aorta } \\
\text { Common iliac }\end{array}$ \\
\hline 9 & F. V. & F & 63 & 51 & 277 & 129 & Type II-a & $83.2^{*}$ & $228 \ddagger$ & $\begin{array}{l}63 \\
68\end{array}$ & $\begin{array}{l}\text { Carotid } \\
\text { Common iliac } \\
\text { Femoral }\end{array}$ \\
\hline 10 & F. S. & $\mathbf{M}$ & 48 & 67 & 229 & 333 & Type IV & $55.9 \ddagger$ & & 69 & $\begin{array}{l}\text { Abdominal aorta } \\
\text { Common iliac }\end{array}$ \\
\hline 11 & N. F. & F & 63 & 47 & 277 & 148 & Type II-a & $86.9 *$ & $226 \ddagger$ & 78 & $\begin{array}{l}\text { Abdominal aorta } \\
\text { Common iliac } \\
\text { Femoral }\end{array}$ \\
\hline 12 & D. $\mathbf{M}$. & $\mathbf{M}$ & 40 & 70 & 185 & 236 & Type IV & $90.6 *$ & $305 \ddagger$ & 81 & $\begin{array}{l}\text { Abdominal aorta } \\
\text { Common iliac }\end{array}$ \\
\hline 13 & R.P. & $\mathbf{M}$ & 55 & 69 & 445 & 162 & Type II-a & $38.3 \ddagger$ & $52.2^{*}$ & 96 & $\begin{array}{l}\text { Aorta (arch, } \\
\text { descending thoracic, } \\
\text { and abdominal) } \\
\text { coronary }\end{array}$ \\
\hline
\end{tabular}

* $\left[4-\mathrm{C}^{14}\right]$ cholesterol.

$\ddagger\left[1,2-\mathrm{H}^{3}\right]$ cholesterol

2,5-diphenyloxazole and $0.1 \mathrm{~g}$ of 1,4-bis[2-(5-phenyloxazolyl)]benzene/liter of toluene) in a Packard Tri-carb liquid scintillation spectrometer, model 3380 (Packard Instrument Co., Inc., Downers Grove, Ill.). This counter was fitted with an absolute activity analyzer (model 544) to provide directly the disintegrations per minute. The radioactivity counter was standardized externally with a series of sealed $\mathrm{C}^{14}$ and $\mathrm{H}^{3}$ quench standards. All samples were counted for three cycle for a minimum count of 10,000 or $100 \mathrm{~min}$. The samples had low quench and always had values (dpm) with an $\mathrm{SD}$ of $2.5 \%$ or less.

Determination of the cholesterol content and sp act in atheromatous arteries. The arterial specimens were washed in four changes of ice-cold saline to remove contaminating blood plasma. After stripping the adventitia, the intact artery was longitudinally opened. The intimal and medial layers were separated along their cleavage planes according to the method described by Wolinsky and Daly (14). The specimens were then analyzed for cholesterol content and radioactivity. In some samples, a superficial layer representing the subendothelial area of the intima was analyzed separately and compared with the underlying deep layer. Also, areas of the artery wall with thrombi or atheromatous abscesses were analyzed separately. Tissues, such as liver and skeletal muscle, were also washed free of blood before analysis.

All tissues were cut and minced with a pair of scissors, placed in precisely weighed beakers, and dried at $60^{\circ} \mathrm{C}$ in vacuo for 48 or more $\mathrm{h}$ to constant weight. The dried tissue was extracted repeatedly with fresh volumes of hot chloroform: methanol $(2: 1)$ over a 2 -day period. The last few extractions were done by grinding the tissue with the hot solvent mixture in a mortar. The lipid extracts were filtered through an ether-washed filter paper into a volumetric flask. Aliquots of this extract were taken for evaporation, saponification with alcoholic $\mathrm{KOH}$ at $70^{\circ} \mathrm{C}$ for $2 \mathrm{~h}$, and re-extraction with hexane. Known aliquots of the hexane extract were used to determine cholesterol by the Liebermann-Burchard reaction (13). Suitable aliquots were also taken for the determination of radioactivity by liquid scintillation counting, as stated before. In view of the smallness of the sample size and its low radioactivity, some of the specimens were analyzed for their cholesterol content by gas-liquid chromatography using cholestane and stigmasterol as internal standards (method described below).

Specific radioactivity of cholesterol was calculated as disintegrations per minute per milligram cholesterol. Tissue cholesterol specific radioactivities were also expressed as 


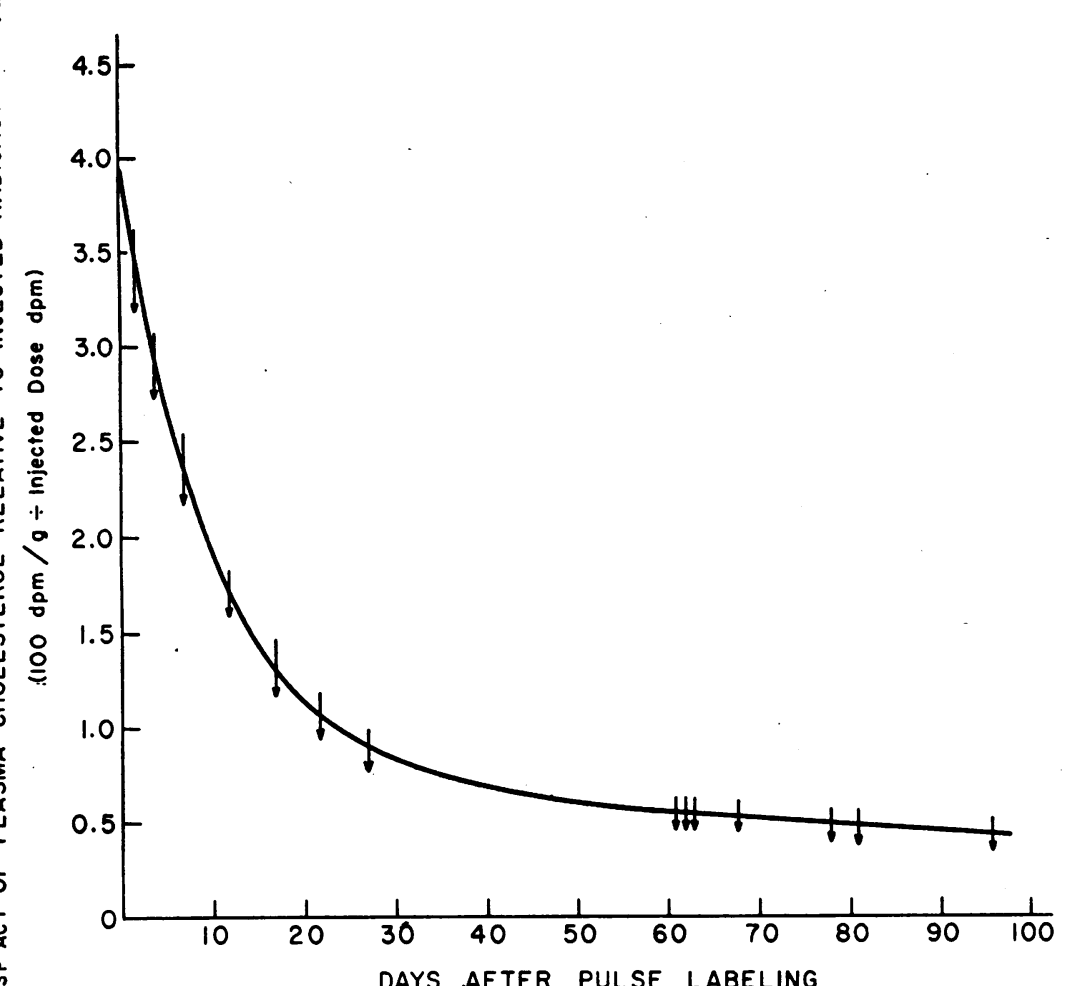

FIGURE 1 A typical decay curve of plasma cholesterol specific activity after pulselabeling with [4- $\left.\mathrm{C}^{14}\right]$ cholesterol. Arrows cutting the curve indicate when the arterial specimens were obtained from the 13 patients studied. In one patient (no. 5), the specimens obtained represented two time points in view of the administration of two different isotopes, 17 and 62 days before surgery.

a percentage relative to plasma cholesterol specific activity at the time of surgery (patients 1-12) or the time of death (patient 13).

Determination of esterified cholesterol. The proportion of ester cholesterol to free cholesterol in the arterial tissues was determined by a gas chromatographic method (Jagannathan and Connor, to be published). The method depends on the principle that, for the preparation of an ether derivative, a free hydroxyl group is needed in the steroid nucleus and that the cholesterol esters do not emerge from the column rapidly under the temperature, flow, and column conditions followed. Cholestane and stigmasterol were added as internal standards and mixed uniformly with a known volume of the tissue lipid extract. Trimethylsilylether derivative of cholesterol was prepared in 2 aliquots, one before saponification (for the free cholesterol fraction) and the other after saponification and extraction (for total cholesterol). The trimethylsilyl-ether derivatives of sterols were separated and quantified at $230^{\circ} \mathrm{C}$ on a $\mathrm{HP}-7610 \mathrm{~A}$ gas chromatograph, fitted with a hydrogen flame ionization detector on a column of SE-30 (3.8\%) on Diatoport S (Hewlett-Packard Co., Palo Alto, Calif.), 80/100 using helium as the carrier gas. This method gave comparable results with an established method described below.

Determination of sp act of free and esterified cholesterol fractions. With a solvent mixture containing hexane: diethyl ether:acetic acid, $80: 20.1$, the free and esterified cholesterol were separated by thin-layer chromatography on silica gel $\mathrm{G}$. The lipid bands were visualized under ultra- violet light after spraying with a $0.2 \%$ solution of rhodamine $\mathrm{G}$ in $50 \%$ ethanol. The free and esterified cholesterol bands were scraped and extracted with $5 \times 5-\mathrm{ml}$ vol of diethyl ether. Pooled ether extracts were evaporated to dryness and redissolved in known volumes of hexane. Suitable aliquots of hexane extract were used to determine cholesterol content and radioactivity, and the sp act was calculated for the free and the esterified fractions. Some arterial specimens were too scanty to permit all of the above determinations.

Plasma cholesterol turnover curve: time periods of obtaining arterial specimens. A typical decay curve of the plasma cholesterol sp act after intravenous pulse labeling with $\left[4-C^{14}\right]$ cholesterol is shown in Fig. 1. The curve exhibits two exponentials for the length of the observed period (15). Each arrow along the curve indicates a time when specimens of atheroma were obtained during surgery for arterial reconstruction in 12 of the 13 patients and at autopsy in the 13th patient. Thus, intimal specimens were obtained from 2 to 96 days after pulse labeling, the periods of time that covered both the early portions and the later (relatively linear) portions of the plasma cholesterol sp act decay curve (Table I).

\section{RESULTS}

The equilibration of cholesterol between plasma and atheroma during the early phase of the plasma sp act decay curve (2-27 days). The ratio of the specific

Turnover of Atheroma Cholesterol in Man 
TABLE II

Equilibration of Cholesterol between Atheroma and Plasma 2-27 Days after Administration of Radiocholesterol (Seven Subjects)

\begin{tabular}{|c|c|c|c|c|c|c|c|}
\hline \multirow{2}{*}{$\begin{array}{l}\text { Days } \\
\text { after } \\
\text { isotope }\end{array}$} & \multirow[b]{2}{*}{$\begin{array}{c}\text { Patient } \\
\text { no. }\end{array}$} & \multirow[b]{2}{*}{ Artery } & \multirow{2}{*}{$\begin{array}{l}\text { Sp act of } \\
\text { plasma } \\
\text { cholesterol }\end{array}$} & \multicolumn{2}{|c|}{ Intimal } & \multirow{2}{*}{$\begin{array}{l}\text { Sp act of } \\
\text { intimal } \\
\text { cholesterol }\end{array}$} & \multirow[b]{2}{*}{$\begin{array}{c}\text { Equili- } \\
\text { bration* }\end{array}$} \\
\hline & & & & $\begin{array}{l}\text { Cholesterol } \\
\text { content }\end{array}$ & Radioactivity & & \\
\hline & & & $d p m / m g$ & $m g / g d r y$ tissue & $d p m / g$ & $d p m / m g$ & $\%$ \\
\hline 2 & 4 & Carotid & 4,163 & 132.0 & 5,808 & 44 & 1.1 \\
\hline \multirow[t]{3}{*}{4} & 1 & Abdominal aorta & 5,224 & 168.4 & 8,588 & 51 & 1.0 \\
\hline & & & & $193.1 \ddagger$ & 7,531 & 39 & 0.7 \\
\hline & & & & $238.7 \ddagger$ & 11,458 & 48 & 0.9 \\
\hline \multirow[t]{2}{*}{4} & 1 & Common iliac & 5,224 & 104.0 & 24,336 & 234 & 4.5 \\
\hline & & & & $112.7 \ddagger$ & 12,397 & 110 & 2.1 \\
\hline 4 & 2 & Common iliac & 3,995 & 267.0 & 3,471 & 13 & 0.3 \\
\hline 7 & 3 & Femoral & 3,773 & 37.6 & 1,506 & 306 & 8.1 \\
\hline 12 & 4 & Abdominal aorta & 1,069 & 30.0 & 630 & 21 & 2.0 \\
\hline 17 & 5 & Abdominal aorta & 3,830 & 95.8 & 67,644 & 706 & 18 \\
\hline \multirow[t]{2}{*}{17} & 5 & Common iliac & 3,830 & 62.3 & 29,219 & 469 & 12 \\
\hline & & & & $65.2 \ddagger$ & 45,053 & 691 & 18 \\
\hline 22 & 6 & Femoral & 710 & 120.4 & 16,736 & 139 & 20 \\
\hline 27 & 7 & Abdominal aorta & 1,030 & 27.0 & 1,836 & 68 & 6.6 \\
\hline 27 & 7 & Common iliac & 1,030 & 25.0 & 1,650 & 66 & 6.4 \\
\hline 27 & 7 & Femoral & 1,030 & 17.0 & 2,550 & 150 & 15 \\
\hline
\end{tabular}

* (Initimal cholesterol sp act/plasma cholesterol sp act) $\times 100$.

$\ddagger$ Specimen from a different location.

radioactivity of cholesterol in the arterial tissue to that in the plasma has been taken as a measure of the equilibration of atheroma cholesterol with plasma cholesterol. In the earliest arterial specimen obtained 2 days after the administration of isotopic cholesterol, the sp act of atheroma cholesterol was only $1 \%$ of the plasma level (Table II). Specimens obtained at 4 days had values, some of which were a little higher, up to $4.5 \%$. By $17-$ 27 days the sp act of cholesterol in the atheroma ranged from 6 to $20 \%$ of the plasma value (with a mean 14\%), whereas, by 22 days, skeletal muscle had a relative sp act of $96 \%$ (vide page 372 ).

The equilibration during the later phase of the plasma sp act decay curve (61-96 days). During periods from 61 to 96 days after isotopic cholesterol when the curve of plasma cholesterol sp act decay was nearly linear, atheroma cholesterol had not completely equilibrated with plasma cholesterol in any of the intimal plaques analyzed (Tables IIIA, IIIB). Atheroma cholesterol in abdominal aorta (nine specimens from seven subjects) had equilibrated to an extent of only $55 \%$ (Fig. 2). The cholesterol of the iliac and femoral atheroma equilibrated even less, $30 \%$ and $26 \%$, respectively. This difference between the different arteries could not be correlated with the respective cholesterol contents. However, all arteries were severely atherosclerotic, and all had high cholesterol contents despite some differences. In patient 13 who died of coronary heart disease 96 days after iso- topic administration, cholesterol of the three coronary arteries had a mean equilibration of $66 \%$, a value equaling that for the abdominal aorta and similar to that found for the thoracic aorta (Fig. 3). Liver cholesterol was completely equilibrated with plasma cholesterol. A heavily involved area of the aortic arch, which had a cholesterol content of $180 \mathrm{mg} / \mathrm{g}$ dry tissue, had an equilibration of only $20 \%$, whereas a nearby less involved area, with a cholesterol concentration of only $30 \mathrm{mg} / \mathrm{g}$, had a higher equilibration at $45 \%$.

The effect of route of administration of the labeled cholesterol (intravenous or oral) upon the equilibration of cholesterol between atheroma and plasma. In 5 subjects who received cholesterol with different labels simultaneously by the intravenous and oral routes, the percent equilibration values obtained for the 2 routes were not significantly different for 14 specimens of abdominal aorta, common iliac, and femoral arteries analyzed (Table IV).

The cholesterol equilibration in different layers of atheromatous plaques and in the free and esterified fractions. Superficial layers of the atheroma, representing the subendothelial region, equilibrated to a significantly higher extent than did the corresponding deep layers in both abdominal aorta and common iliac artery (Table V). The mean equilibration was $75 \%$ in the superficial layer compared with only $22 \%$ for the deep 
TABLE IIIA

Equilibration between Atheroma Cholesterol and Plasma Cholesterol 61-96 Days after Intravenous Labeling with Radiocholesterol (Abdominal Aorta, Common Iliac Artery)

\begin{tabular}{|c|c|c|c|c|c|c|c|}
\hline \multirow[b]{2}{*}{ Artery } & \multirow[b]{2}{*}{$\begin{array}{c}\text { Patient } \\
\text { no. }\end{array}$} & \multirow[b]{2}{*}{$\begin{array}{c}\text { Days after } \\
\text { isotope }\end{array}$} & \multirow{2}{*}{$\begin{array}{l}\text { Sp act of } \\
\text { plasma } \\
\text { cholesterol }\end{array}$} & \multicolumn{2}{|c|}{ Intimal } & \multirow{2}{*}{$\begin{array}{l}\text { Sp act of } \\
\text { intimal } \\
\text { cholesterol }\end{array}$} & \multirow[b]{2}{*}{$\begin{array}{c}\text { Equili- } \\
\text { bration* }\end{array}$} \\
\hline & & & & $\begin{array}{l}\text { Cholesterol } \\
\text { content }\end{array}$ & Radioactivity & & \\
\hline & & & $d p m / m g$ & $m g / g d r y w t$ & $d p m / g d r y w t$ & $d p m / m g$ & $\%$ \\
\hline \multirow[t]{9}{*}{ Abdominal aorta } & 5 & 62 & 704 & 95.8 & 31,518 & 329 & 47 \\
\hline & 8 & 61 & 110 & 137.9 & 12,135 & 88 & 80 \\
\hline & & & & $153.2 \ddagger$ & 12,716 & 83 & 75 \\
\hline & 10 & 69 & 328 & 103.2 & 3,406 & 33 & 10 \\
\hline & & & & $123.6 \pm$ & 11,866 & 96 & 29 \\
\hline & 11 & 78 & 697 & 114.9 & 66,527 & 579 & 83 \\
\hline & & & & $45.4_{\ddagger}^{+}$ & 24,788 & 546 & 78 \\
\hline & 12 & 81 & 575 & 154.8 & 26,935 & 174 & 30 \\
\hline & 13 & 96 & 74 & 122.3 & 5,993 & 49 & 66 \\
\hline Mean \pm SE & & & & $116.8 \pm 11.19$ & & & $55.3 \pm 9.01$ \\
\hline \multirow[t]{9}{*}{ Common iliac } & 5 & 62 & 704 & 62.3 & 19,126 & 307 & 44 \\
\hline & & & & $65.2_{\ddagger}^{+}$ & 19,625 & 301 & 43 \\
\hline & 8 & 61 & 110 & 56.4 & 2,312 & 41 & 37 \\
\hline & 9 & 68 & 851 & 41.8 & 8,444 & 202 & 24 \\
\hline & 10 & 69 & 328 & 100.7 & 12,285 & 122 & 37 \\
\hline & & & & $134.3_{\ddagger}^{+}$ & 8,595 & 64 & 20 \\
\hline & 11 & 78 & 697 & 106.6 & 36,670 & 344 & 49 \\
\hline & 12 & 81 & 575 & 128.6 & 7,202 & 56 & 10 \\
\hline & & & & $107.8_{\ddagger}^{+}$ & 5,498 & 51 & 9 \\
\hline Mean \pm SE & & & & $89.3 \pm 11.17$ & & & $30.3 \pm 5.00$ \\
\hline
\end{tabular}

* (Tissue cholesterol sp act/plasma cholesterol sp act) $\times 100$.

‡ Specimen from a different location.

TABLE IIIB

Equilibration between Atheroma Cholesterol and Plasma Cholesterol 63-96 Days after Intravenous Labeling with Radiocholesterol (Femoral, Coronary, and Carotid Arteries, the Arch and the Thoracic Aorta)

\begin{tabular}{|c|c|c|c|c|c|c|c|}
\hline \multirow[b]{2}{*}{ Artery } & \multirow[b]{2}{*}{$\begin{array}{c}\text { Patient } \\
\text { no. }\end{array}$} & \multirow[b]{2}{*}{$\begin{array}{l}\text { Days after } \\
\text { isotope }\end{array}$} & \multirow{2}{*}{$\begin{array}{l}\text { Sp act of } \\
\text { plasma } \\
\text { cholesterol }\end{array}$} & \multicolumn{2}{|c|}{ Intimal } & \multirow{2}{*}{$\begin{array}{l}\text { Sp act of } \\
\text { intimal } \\
\text { cholesterol }\end{array}$} & \multirow[b]{2}{*}{$\begin{array}{l}\text { Equili- } \\
\text { bration* }\end{array}$} \\
\hline & & & & $\begin{array}{l}\text { Cholesterol } \\
\text { content }\end{array}$ & Radioactivity & & \\
\hline & & & $d p m / m g$ & $m g / g d r y w t$ & $d p m / g d r y w t$ & $d p m / m g$ & $\%$ \\
\hline Femoral & 9 & 68 & 851 & 46.1 & 6,362 & 138 & 16 \\
\hline \multirow[t]{2}{*}{ Femoral } & 11 & 78 & 697 & 61.8 & 12,978 & 210 & 30 \\
\hline & & & & $47.5_{\ddagger}^{+}$ & 10,876 & 229 & 33 \\
\hline Mean & & & & 51.8 & & & 26.3 \\
\hline Right coronary & 13 & 96 & 74 & 55.7 & 2,228 & 40 & 54 \\
\hline \multicolumn{8}{|l|}{ Left coronary } \\
\hline Circumflex & 13 & 96 & 74 & 58.7 & 2,935 & 50 & 68 \\
\hline Anterior descending & 13 & 96 & 74 & 39.7 & 2,223 & 56 & 76 \\
\hline Mean & & & & 51.4 & & & 66 \\
\hline Carotid & 9 & 63 & 949 & 170 & 23,800 & 140 & 15 \\
\hline Arch & 13 & 96 & 74 & 180.9 & 2,714 & 15 & 20 \\
\hline Thoracic Aorta & 13 & 96 & 74 & 88.4 & 4,332 & 42 & 57 \\
\hline
\end{tabular}

* (Tissue cholesterol sp act/plasma cholesterol sp act) $\times 100$.

$\ddagger$ Specimen from a different location. 


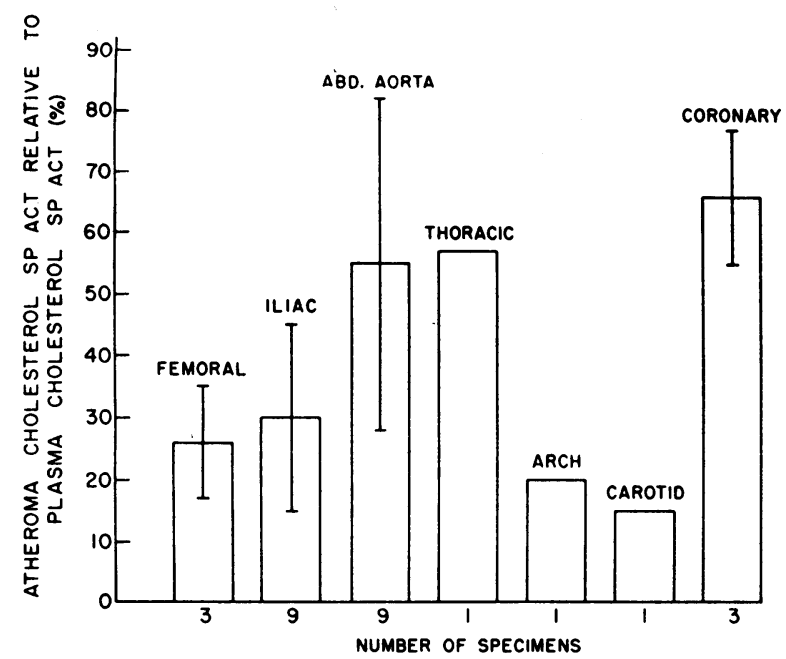

FIGURE 2 The comparative picture of equilibration of atheroma cholesterol with plasma cholesterol in different arteries, 61-96 days after intravenous pulse labeling with isotopic cholesterol. The brackets in each bar indicate the standard deviation.

layer. The concentration of cholesterol in the two layers was, however, similar.

Atheromatous abscesses, even when superficially located, had poor equilibration. Patient 12 , in particular, had several atheromatous abscesses; the equilibration was only $22 \%$ in the abscess found in the right common iliac artery and $36 \%$ in that in the distal aorta. Thrombi were occasionally found attached to atheromatous plaques of the distal aorta and were analyzed along

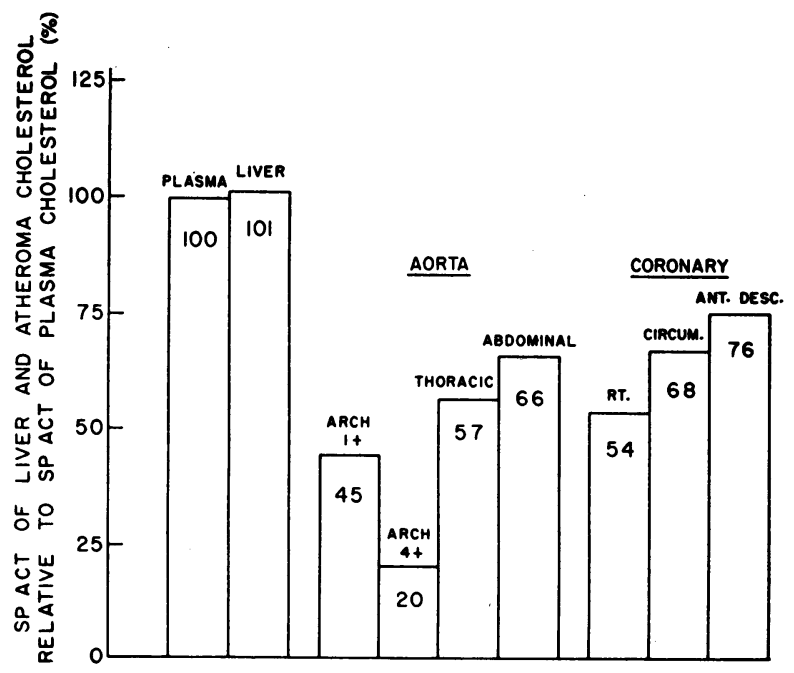

FIGURE 3 Relative equilibration of cholesterol in different arteries and in liver from patient 13, who died 96 days after intravenous pulse-labeling with $\left[1,2-\mathrm{H}^{3}\right]$ cholesterol. The amount of atherosclerosis was different for two areas of the aortic arch and is so indicated by " $1+$ " and " $4+$ ".
TABLE IV

Equilibration between Atheroma Cholesterol and Plasma Cholesterol: A Comparison of Route of Administration of Isotopic Cholesterol (i.v. or Oral)

\begin{tabular}{|c|c|c|c|c|c|}
\hline \multirow[b]{2}{*}{ Artery } & \multirow{2}{*}{$\begin{array}{l}\text { No of } \\
\text { sub- } \\
\text { jects }\end{array}$} & \multirow{2}{*}{$\begin{array}{l}\text { No of } \\
\text { speci- } \\
\text { mens }\end{array}$} & \multirow{2}{*}{$\begin{array}{c}\text { Days } \\
\text { after } \\
\text { isotope }\end{array}$} & \multicolumn{2}{|c|}{ Equilibration* } \\
\hline & & & & Intravenous & Oral \\
\hline & & & & $\%$ & $\%$ \\
\hline Abdominal aorta & 4 & 6 & $61-96$ & $68.7 \pm 8.09 \ddagger$ & $63.3 \pm 8.06$ \\
\hline Common iliac & 4 & 5 & $61-81$ & $25.8 \pm 7.74$ & $24.8 \pm 8.24$ \\
\hline Femoral & 2 & 3 & $68-78$ & $26.3 \pm 5.24$ & $30.0 \pm 1.00$ \\
\hline
\end{tabular}

* (Arterial cholesterol sp act/plasma cholesterol sp act) $\times 100$. $\ddagger$ Mean \pm SE.

with the underlying intima. Thrombi found in two locations of the distal aorta of patient 8 had cholesterol concentrations of 6.1 and $7.1 \mathrm{mg} / \mathrm{g}$ dry matter, respectively. Corresponding cholesterol sp act's were 157 and $111 \%$ that of plasma. The underlying intimal plaques had cholesterol concentrations of 138 and $153 \mathrm{mg} / \mathrm{g}$ dry weight and were equilibrated up to 80 and $75 \%$, respectively.

The specific activities of cholesterol in the atherosclerotic intima and media were compared in seven specimens of abdominal aorta and common iliac artery obtained from four subjects (Table VI). The intima had a mean cholesterol concentration of $85.5 \mathrm{mg} / \mathrm{g}$; the corresponding media had a value of only $5.3 \mathrm{mg} / \mathrm{g}$, which indicated that the media analyzed was relatively uncontaminated by intimal cholesterol. The mean sp act of cholesterol in the media was four times greater than that in the intimal plaque ( 916 vs. $230 \mathrm{dpm} / \mathrm{mg}$ ).

Esterified cholesterol constituted about $67 \%$ of the total cholesterol in 13 specimens of atheromatous plaques analyzed. The esterified fraction of atheroma cholesterol had equilibrated with plasma cholesterol only to an extent of $38 \%$, whereas the free cholesterol fraction equilibrated $(59 \%)$ to a significantly higher extent $(P<0.01)$ in studies carried out from 61 to 78 days after the administration of isotopic cholesterol (Table VII).

The equilibration of cholesterol between plasma and the skeletal muscle. Cholesterol of the skeletal muscle had the following relative sp act values: $20 \%$ by 4 days (patient 1 ), $44 \%$ by 7 days (patient 3 ), 66\% by 12 days (patient 4 ), $96 \%$ by 22 days (patient 6 ), and $127 \%$ by 62 days (patient 5 ) after the administration of isotopic cholesterol.

The estimated influx rate of plasma cholesterol into the arterial intima and the turnover time of atheroma cholesterol. It is possible to estimate, with certain assumptions (16), the influx of plasma cholesterol into the arterial intima over a period of time, $t$ (days after labeling with radiocholesterol), by using the following 
TABLE V

Equilibration between Atheroma Cholesterol and Plasma Cholesterol in Superficial and Deep Layers of the Plaque

\begin{tabular}{|c|c|c|c|c|c|c|c|}
\hline \multirow[b]{3}{*}{ Artery } & \multirow{3}{*}{$\begin{array}{l}\text { Patient } \\
\text { no. }\end{array}$} & \multicolumn{3}{|c|}{ Superficial_layer } & \multicolumn{3}{|c|}{ Deep layer } \\
\hline & & \multicolumn{2}{|c|}{ Cholesterol } & \multirow[b]{2}{*}{ Equilibration* } & \multicolumn{2}{|c|}{ Cholesterol } & \multirow[b]{2}{*}{ Equilibration* } \\
\hline & & Content & Sp act & & Content & Sp act & \\
\hline & & $m g / g$ & $d p m / m g$ & $\%$ & $m g / g$ & $d p m / m g$ & $\%$ \\
\hline Left common iliac & 8 & 97.5 & 78 & 71 & 39.4 & 32 & 29 \\
\hline Left common iliac & 12 & 51.5 & 499 & 87 & 100.7 & 16 & 3 \\
\hline Right common iliac & 12 & 28.2 & 345 & 60 & 77.0 & 41 & 7 \\
\hline Abdominal aorta & 5 & 109.2 & 480 & 68 & 78.7 & 188 & 27 \\
\hline Abdominal aorta & 11 & 80.0 & 620 & 89 & 64.8 & 319 & 46 \\
\hline Mean \pm SE & & $73.3 \pm 14.90$ & & $75.0 \pm 5.61$ & $72.1 \pm 10.02$ & & $22.4 \pm 7.86$ \\
\hline
\end{tabular}

* (Tissue cholesterol sp act/plasma cholesterol sp act) $\times 100$.

relationship :

Total influx (mg)

$=\frac{\text { radioactivity }(\mathrm{dpm}) \text { per unit dry weight of intima }}{\text { an expression of the average } \mathrm{sp} \text { act of plasma }}$ cholesterol over the period since labeling

$$
\begin{aligned}
& =\frac{\mathrm{dpm} / \mathrm{g} \text { dry intima }}{\text { area under the plasma cholesterol sp act-time }} \\
& \text { curve } \div \text { no. of days }
\end{aligned}
$$

Influx rate ( $\mathrm{mg}$ cholesterol/g dry intima per day)

$$
=\frac{\mathrm{dpm} / \mathrm{g} \text { intimal tissue }}{\text { area under the plasma cholesterol }}
$$

In the above relationship, it is assumed that efflux of radioactivity out of arterial intima is negligible or minimal over the duration of the study. This assumption does not as yet have definite experimental support. In view of this, it is more appropriate to consider the influx rate derived by these calculations as the minimal estimate of the transfer of plasma cholesterol into the arterial intima. This minimal estimate of the influx rate studied 61-96 days after pulse labeling ranged from $0.065 \mathrm{mg}$ cholesterol $/ \mathrm{g}$ dry tissue per day for the femoral artery to $0.157 \mathrm{mg}$ for the common iliac artery and $0.274 \mathrm{mg}$ for the abdominal aorta (distal) (Table VIII). The coronary arteries showed a minimal influx rate of $0.116 \mathrm{mg}$ plasma cholesterol/g dry tissue per day.

Since it is known that in situ synthesis of cholesterol does not contribute significantly to the pool of accumulated intimal cholesterol $(16,17)$, one could derive conditionally the following two maximal estimates from a knowledge of the cholesterol concentration of the atheromatous tissue and the minimal influx rate (Table VIII).

\begin{tabular}{|c|c|c|c|c|c|c|c|c|}
\hline \multirow{3}{*}{$\begin{array}{c}\text { Patient } \\
\text { no. }\end{array}$} & \multirow{3}{*}{$\begin{array}{c}\text { Plasma } \\
\text { choles- } \\
\text { terol } \\
\text { sp act }\end{array}$} & \multirow[b]{3}{*}{ Artery } & \multicolumn{3}{|c|}{ Arterial intima } & \multicolumn{3}{|c|}{ Arterial media } \\
\hline & & & \multicolumn{2}{|c|}{ Cholesterol } & \multirow{2}{*}{$\begin{array}{l}\text { Equili- } \\
\text { bration* }\end{array}$} & \multicolumn{2}{|c|}{ Cholesterol } & \multirow{2}{*}{$\begin{array}{l}\text { Equili- } \\
\text { bration* }\end{array}$} \\
\hline & & & Content & Sp act & & Content & Sp act & \\
\hline & $d p m / m g$ & & $m g / g$ & $d p m / m g$ & $\%$ & $m g / g$ & $d p m / m g$ & $\%$ \\
\hline \multirow[t]{3}{*}{5} & 704 & Abdominal aorta & 95.8 & 329 & 47 & 3.47 & 1,317 & 187 \\
\hline & & Right common iliac & 62.3 & 307 & 44 & 3.75 & 1,101 & 156 \\
\hline & & Left common iliac & 65.2 & 301 & 43 & 2.50 & 1,283 & 182 \\
\hline 9 & 851 & Common iliac & 41.8 & 202 & 24 & 2.25 & 1,351 & 159 \\
\hline \multirow[t]{2}{*}{10} & 328 & Abdominal aorta & 103.2 & 33 & 10 & 7.40 & 260 & 79 \\
\hline & & Abdominal aorta & 123.6 & 96 & 29 & 8.10 & 297 & 91 \\
\hline 11 & 575 & Common iliac & 106.6 & 344 & 49 & 9.66 & 803 & 115 \\
\hline \multicolumn{2}{|c|}{ Mean \pm SE } & & $85.5 \pm 11.10$ & $230.3 \pm 46.63$ & $35.1 \pm 5.49$ & $5.30 \pm 1.13$ & $916.0 \pm 178.97$ & $138.4 \pm 16.42$ \\
\hline
\end{tabular}

TABLE VI

The Relative Equilibration of Cholesterol in the Intima and the Media of Atheromatous Arteries, 62-78 Days after i.v. Labeling with Radiocholesterol

* (Arterial cholesterol sr act/plasma cholesterol sp act) $\times 100$. 
TABLE VII

Relative Equilibration in Free Cholesterol (FC) and Esterified Cholesterol (CE) Fractions of Atheroma Cholesterol

\begin{tabular}{|c|c|c|c|c|c|}
\hline \multirow{2}{*}{$\begin{array}{c}\text { Patient } \\
\text { no. }\end{array}$} & \multirow[b]{2}{*}{ Artery } & \multicolumn{2}{|c|}{ Specific activity } & \multicolumn{2}{|c|}{ Equilibration* } \\
\hline & & $\mathrm{FC}$ & $\mathrm{CE}$ & $\mathrm{FC}$ & $\mathrm{CE}$ \\
\hline & & \multicolumn{2}{|c|}{$d p m / m g$} & \multicolumn{2}{|c|}{$\%$} \\
\hline 5 & Abdominal aorta & 420 & 270 & 60 & 38 \\
\hline 5 & Left common iliac & 312 & 300 & 44 & 43 \\
\hline 5 & Right common iliac & 378 & 251 & 54 & 36 \\
\hline 8 & Right common iliac & 65 & 54 & 59 & 49 \\
\hline 8 & Left common iliac & 43 & 29 & 39 & 26 \\
\hline \multirow[t]{2}{*}{11} & Abdominal aorta & 663 & 259 & 95 & 37 \\
\hline & Mean \pm SE & & & $\ddagger 58.5 \pm 8.05$ & $38.2 \pm 3.14$ \\
\hline
\end{tabular}

* (Arterial cholesterol sp act/plasma cholesterol sp act) $\times 100$. $\ddagger P<0.01$.

cholesterol content of atheromatous artery (mg/g dry tissue)

influx rate ( $\mathrm{mg}$ cholesterol/g dry

tissue per day)

$$
=\text { accumulation time } e^{3} \text { in days }
$$

Substituting E 1 in the left-hand side of the above E 2,

Area under the plasma cholesterol

$$
\begin{aligned}
\frac{\text { sp act decay curve }}{\text { sp act of atheroma cholesterol }} & =\frac{1}{\begin{array}{c}
\text { fractional } \\
\text { turnover } \\
\text { rate }
\end{array}} \\
& =\text { turnover time }
\end{aligned}
$$

The maximal estimates of turnover time derived as above for the different arteries were as follows: abdominal aorta, $442 \pm 50$ (SE) days; coronary arteries, $443 \pm$ 45 days; common iliac artery, $580 \pm 88$ days; and femoral artery, $821 \pm 82$ days (Table VIII).

\section{DISCUSSION}

The crucial question about advanced atherosclerotic lesions in man is whether they conceivably can undergo regressive changes such that improvement of blood flow might result. The direct approach to this question not being possible in man, one must then either draw inferences from the evidence about regression in experimental animals or else design human experiments utilizing atherosclerotic lesions obtainable at the time of surgery or at autopsy. In animals, regression has been demonstrated by morphological changes and by chemical changes, i.e., by a reduction in cholesterol content. In man, since a similar type of controlled experiment can-

\footnotetext{
${ }^{3}$ If there was no significant efflux of atheroma cholesterol.

- If atheroma cholesterol was indeed in a steady state with influx being equal to efflux.
}

not be carried out, perhaps an indirect study could provide some information about the possibilities of regression. An example of an indirect study would be the measurement of cholesterol turnover in the atherosclerotic artery. If cholesterol in the arterial wall does not exchange with cholesterol in the blood, it is clearly contained in an inert pool within the atheroma. Under that circumstance, it would be unlikely that any regression would occur. For regression to occur, cholesterol must be mobilizable, and, if there is no exchange of cholesterol between blood and arterial wall, then there is no likelihood of cholesterol being transferred out of the artery. There is no evidence to suggest that cholesterol may be metabolized in situ in either the normal artery or the atheromatous arterial intima. The tissues of animals and man cannot metabolize the steroid nucleus, i.e., the basic steroid ring structure once deposited in the tissues remains intact. Thus, the techniques of isotopic cholesterol exchange and turnover might well be employed in patients from whom atheromatous specimens were obtained in order to obtain information in this important area of concern.

In the monkey, a considerable amount of regression occurred during hypocholesterolemic dietary regimens, the lesions decreasing from about $60 \%$ occlusion of the coronary tree to about $20 \%$ occlusion as judged by morphological criteria (9). Chemically, this regression was represented by the removal of $64 \%$ of the cholesterol contained in the original atherosclerotic lesion (18). Isotopic techniques have also revealed that the atherosclerotic monkey aorta exchanges cholesterol with the plasma as readily as the normal aorta (Jagannathan and Connor; Connor and Wissler, unpublished observations). On the other hand, the atherosclerotic rabbit aorta failed to regress, and at the same time, it did not exchange its cholesterol with that of the plasma (19). This composite of information suggests that the exchangeability of 
cholesterol between atheroma and plasma may be taken as an important indication of the possible regression of atherosclerosis. In our human study, the cholesterol contained in clinically significant and severely obstructive atherosclerotic lesions had the capacity to equilibrate with the plasma cholesterol up to $55 \pm 9.0 \%$ (SE) for the abdominal aorta by 61-96 days, for example.

On the other hand, in our study, the sp act of atheroma cholesterol never equaled the sp act of the plasma cholesterol, despite time periods up to 96 days after the intravenous administration of isotopic cholesterol. The equilibration averaged from 30 to $66 \%$ for various arteries. We interpret these data as follows. Considerable equilibration between the cholesterol of plasma and atheroma did indeed occur in severely obstructive atherosclerotic plaques. Hypothetically, the sp act curve of atheroma cholesterol would ultimately cross the declining sp act curve of the plasma cholesterol. Clearly, with severe atherosclerosis and a very large pool of unlabeled cholesterol which would dilute greatly the entering labeled cholesterol, a longer time period would be required for equilibration. In other studies, when the lesions were less severe and the time periods longer, from 137 to 371 days, this crossover phenomenon of atheroma and plasma cholesterol sp act was demonstrated $(3,5,7)$.

While our results were somewhat comparable to those of previous studies (2-6), the present investigation differs in the following major respects: $(a)$ it was conducted in 12 living patients. All previous studies were carried out at autopsy, generally in patients with neoplastic disease. (b) 12 out of the 13 patients in the present investigation had severe peripheral obstructive atherosclerosis with intermittent claudication or cerebral ischemia. The atherosclerotic lesions in all of these patients were advanced and included, in some locations, atheromatous abscesses, calcification, and thrombi. The arterial specimens analyzed from these patients had very high concentrations of cholesterol $(51-151 \mathrm{mg} / \mathrm{g}$ dry tissue), as compared to the values reported in the literature for "normal" human arteries (viz., about $4 \mathrm{mg}$ cholesterol/g dry tissue) (20). Many of the patients from the previous studies had less severe atherosclerotic lesions. (c) The 13 patients of this investigation were better defined as to the discrete type of hyperlipoproteinemia that was present.

The fact that these completely obstructed arteries had considerable uptake of radio-labeled cholesterol from the blood calls into question how such an interchange can occur. Unlike the normal artery whose intima contains no blood vessels, the atheromatous intima is heavily vascularized by vessels from the adventitia and media (vasa vasorum) and, even in some instances, by vessels from the lumen. Thus, the cholesterol contained in atheromatous plaques might exchange with the plasma cholesterol flowing through the lumen of the artery or via the vasa vasorum. Media, subserved completely by the vasa vasorum, equilibrated much more readily with the plasma cholesterol than did atheroma. The cholesterol of thrombi overlying plaques but attached to them appeared to be completely equilibrated with the plasma cholesterol. The actual specific activity undoubtedly depended upon the age of the thrombi in relation to the changing plasma cholesterol specific activity. On the other hand, deeper layers of the plaques, presumably older, less vascular, and containing more crystalline cholesterol, equilibrated less well than the superficial layers (22 vs. $75 \%$ ). Another tissue, xanthoma, which like the atheroma has a very high cholesterol content, equilibrates, however, more readily with the plasma

TABLE VIII.

Estimates of Minimal Influx of Plasma Cholesterol Into Atheromatous Intima: Approximation of Accumulation* or Turnover $\$$ Time of Atheroma Cholesterol

\begin{tabular}{lcccccc}
\hline \multicolumn{1}{c}{ Artery } & $\begin{array}{c}\text { No of } \\
\text { subjects }\end{array}$ & $\begin{array}{c}\text { No of } \\
\text { specimens }\end{array}$ & $\begin{array}{c}\text { Days after } \\
\text { isotope }\end{array}$ & $\begin{array}{c}\text { Cholesterol } \\
\text { content }\end{array}$ & Influx rate & $\begin{array}{c}\text { Estimate of } \\
\text { accumulation* } \\
\text { or turnover } \\
\text { time }\end{array}$ \\
\hline Abdominal aorta & 6 & 8 & $61-96$ & $119 \pm 12.58$ & $0.274 \pm 0.027$ & $442 \pm 49.6$ \\
Common iliac & 5 & 7 & $61-78$ & $81 \pm 12.6$ & $0.157 \pm 0.028$ & $580 \pm 87.6$ \\
Femoral & 2 & 3 & 68,78 & $52 \pm 5.0$ & $0.065 \pm 0.010$ & $821 \pm 82.1$ \\
Carotid & 1 & 1 & 63 & 170 & 0.182 & 934 \\
Coronary & 1 & 3 & 96 & $51 \pm 5.9$ & $0.116 \pm 0.011$ & $443 \pm 45.2$ \\
\hline
\end{tabular}

* If the efflux of atheroma cholesterol was negligible, this would be the maximal period of accumulation.

$\ddagger$ If atheroma cholesterol was indeed in a steady state (when influx equals efflux), this would also be the maximal turnover time. $\$ \mathrm{SE}$. 
cholesterol (21). Its greater equilibration (relative sp act of $82 \%$ at 28 days and $534 \%$ at 122 days) may be accounted for by its greater vascularity and cellularity with fewer areas of necrosis.

An indication of active cholesterol metabolism in even severely obstructed atherosclerotic plaques was provided not only by the uptake of free cholesterol from the plasma but also by the occurrence of radioactive cholesterol ester. This later feature may be explained by: (a) the direct uptake of isotopic cholesterol ester from the plasma, a process considered to occur, if at all, at a very slow rate, and/or $(b)$ by the esterification of free cholesterol which has already entered the plaque. In vitro studies using human arteries from cadaveric renal transplant donors have demonstrated significant cholesterol-esterifying activity in early atherosclerotic (foam cell) lesions (22). The findings in the present investigation indicate the presence of an active cholesterol esterification system even in advanced atherosclerotic lesions in man.

The free cholesterol fraction of the atheroma equilibrated with the plasma cholesterol to a significantly greater extent than did the esterified fraction (59 vs. $38 \%$ ). These data are evidence against the origin of most of the plaque cholesterol ester being derived from the plasma cholesterol ester, since free and ester cholesterol are completely equilibrated in the plasma (23). They support the view that the origin of much of the cholesterol ester in the plaque is through in situ esterification of free cholesterol with the arterial wall fatty acid. When a large amount of free cholesterol enters the arterial wall in the development of the atherosclerotic plaque, the excess is apparently stored in the form of the more inert cholesterol ester. Free cholesterol entered the atherosclerotic plaque also more readily in the rabbit (16).

The lack of correlation between the cholesterol content of the artery and the equilibration of its cholesterol with the plasma cholesterol is in contrast with observations in experimental animals. With increasing atheromatosis, a faster rate of plasma cholesterol influx into the arteries has been reported in the rabbit (16) and the white Carneau pigeon (24). These experimental lesions were of the fatty streak type and were predominantly intracellular, unlike the advanced relatively acellular lesions studied in man in the present investigation. Whether the early intracellular human lesions would also show accelerated influx of plasma cholesterol is a moot question. Besides, it could be that in advanced lesions with extracellular cholesterol and calcification the blood supply to the arterial intima per unit of mass may be limited. These factors could have contributed to the lower equilibration of cholesterol in these advanced human lesions.
The minimal influx rates of plasma cholesterol into the atheromatous plaque estimated in the present study were from 0.065 to $0.274 \mathrm{mg} / \mathrm{g}$ dry intimal tissue per day for different arteries. Using a slightly different experimental approach, Gould, Wissler, and Jones found this rate to be about $0.28-0.35 \mathrm{mg} / \mathrm{g}$ for the aorta and the coronary artery from patients with limited life expectancy (6). Field, Swell, Schools, and Treadwell obtained a somewhat higher value $(0.35-0.46 \mathrm{mg})$ for turnover rate for "normal-appearing" aortic intima (3).

The influx rates were estimated with the assumption that efflux of radioactivity from the artery was minimal during the period of measurement (Table VIII). If no efflux had occurred, the entire amount of cholesterol in the abdominal aorta would have accumulated over a period of 400-500 days (Table VIII). Since the accumulation of cholesterol in the aortic plaque obviously takes place over a period of many years, one must conclude that the cholesterol in atheromatous plaques is in a state of flux. There is another observation in the present study which indicates the occurrence of efflux. In patient 5, who received labeled cholesterol at two time points before surgery (17 and 62 days), the sp act of atheroma cholesterol per unit dose of injected radioactivity was lower at 62 days than at 17 days in both abdominal aorta and common iliac artery. The minimal influx rates were, therefore, higher at the earlier period ( 0.55 vs. 0.27 for abdominal aorta and 0.37 vs. 0.17 for the common iliac artery). If there had been no efflux of radioactivity during the experimental period, the values for influx rate should have been similar for both periods. It is concluded, therefore, that there is definite efflux of radioactivity from atheromatous arteries in man.

Some correction for the efflux of radioactivity from the artery is possible (25) by subtracting the area under the tissue sp act curve from the area under plasma sp act curve in Eq. 3. However, since the tissue sp act curve did not follow the first-order kinetics (patient 5), and since there is no accurate way of predicting its shape, the turnover times estimated in the present study were not compensated for the loss of tissue radioactivity. If atheroma cholesterol had achieved a steady state, the data (Table VIII) should indicate a maximal estimate of turnover time. If efflux is sluggish and/or influx is active, or if a diet or drug should specifically facilitate efflux and/or reduce influx, estimates for turnover time would be much different. The occurrence of definite efflux of radioactivity even from such obstructive atherosclerotic lesions suggests further that the cholesterol in atherosclerotic lesions in man is potentially mobilizable. A better conceptual framework is yet to be devised to make possible more accurate measurements of influx, efflux and fractional turnover rates of atheroma cholesterol. 


\section{ACKNOWLEDGMENTS}

The authors have pleasure in acknowledging the technical assistance rendered by Ms. Linda Cherner, Ms. Bess Gold, and Mr. Richard Stenabaugh.

This study was supported by U. S. Public Health Service Research Grant, HE 14,230 to Specialized Center for Research in Arteriosclerosis, Research Career Development Award HE-K3-18406 (Dr. Connor) from the National Heart and Lung Institute, and also by the General Clinical Research Centers program (RR-59) of the Division of Research Resources, National Institutes of Health.

\section{REFERENCES}

1. Jagannathan, S. N., W. E. Connor, W. H. Baker, and A. K. Bhattacharyya. 1972. Cholesterol turnover in human atheromatous arteries. Circulation. 46: 252. (Abstr.)

2. Biggs, M. W., D. Kritchevsky, D. Colman, J. W. Gofman, H. B. Jones, F. T. Lindgren, G. Hyde, and T. P. Lyon. 1952. Observations on the fate of ingested cholesterol in man. Circulation. 6: 359-366.

3. Field, H., L. Swell, P. E. Schools, and C. R. Treadwell. 1960. Dynamic aspects of cholesterol metabolism in different areas of the aorta and other tissues in man and their relationship to atherosclerosis. Circulation. 22 : $547-558$.

4. Kurland, G. S., J. L. Lucas, and A. S. Freedberg. 1961. The metabolism of intravenously infused $\mathrm{C}^{14}$-labeled cholesterol in euthyroidism and myxedema. J. Lab. Clin. Med. 57: 574-585.

5. Chobanian, A. V., and W. Hollander. 1962. Body cholesterol metabolism in man. I. The equilibration of serum and tissue cholesterol. J. Clin. Invest. 41: 17321737.

6. Gould, R. G., R. W. Wissler, and R. J. Jones. 1963. The dynamics of lipid deposition in arteries. In Evolution of the Atherosclerotic Plaque. R. J. Jones, editor. University of Chicago Press, Chicago. 205-214.

7. Samuel, P., W. Perl, C. M. Holtzmann, N. D. Rochman, and S. Lieberman. 1972. Long-term kinetics of serum and xanthoma cholesterol radioactivity in patients with hypercholesterolemia. J. Clin. Invest. 51: 266-278.

8. Nilsson, A., and D. B. Zilversmit. 1972. Fate of intravenously administered particulate and lipoprotein cholesterol in the rat. J. Lipid Res. 13: 32-38.

9. Armstrong, M. L., E. D. Warner, and W. E. Connor. 1970. Regression of coronary atherosclerosis in Rhesus monkeys. Circ. Res. $27: 59-67$.

10. Fredrickson, D. S., R. I. Levy, and R. S. Lees. 1967. Fat transport in lipoproteins-an integrated approach to mechanisms and disorders. N. Engl. J. Med. 276: 34-44, 94-103, 148-156, 215-225, 273-281.

11. Beaumont, J. L., L. A. Carlson, G. R. Cooper, Z. Fejfar, D. S. Fredrickson, and T. Strasser. 1970. Classification of hyperlipidaemias and hyperlipoproteinemias. Bull. W. H. O. 43: 891-908.

12. Connor, W. E., and D. S. Lin. 1974. The intestinal absorption of dietary cholesterol by hypercholesterolemic (type II) and normocholesterolemic humans. $J$. Clin. Invest. 53: 1062-1070.

13. Abell, L. L., B. B. Levy, B. B. Brodie, and F. E. Kendall. 1952. A simplified method for the estimation of total cholesterol in serum. J. Biol. Chem. 195: 357-366.

14. Wolinsky, H., and M. M. Daly. 1970. A method for the isolation of intima-media samples from arteries. Proc. Soc. Exp. Biol. Med. 135 : 364-368.

15. Goodman, D. S., and R. P. Noble. 1963. Turnover of plasma cholesterol in man. J. Clin. Invest. 47 : 231-241.

16. Newman, H. A. I., and D. B. Zilversmit. 1962. Quantitative aspects of cholesterol flux in rabbit atheromatous lesions. J. Biol. Chem. 237: 2078-2084.

17. Azarnoff, D. L. 1958. Species differences in cholesterol biosynthesis by arterial tissue. Proc. Soc. Exp. Biol. Med. $98: 680$.

18. Armstrong, M. L., and M. B. Megan. 1972. Lipid depletion in atheromatous coronary arteries in Rhesus monkeys after regression diets. Circ. Res. 30: 675-680.

19. Connor, W. E., M. L. Armstrong, C. S. Jackson, and A. M. Ali. 1966. Persistence of cholesterol-4-C ${ }^{14}$ in atherosclerotic aortas of animals treated with a diet high in polyunsaturated fat. J. Clin. Invest. 45: 997. (Abstr.)

20. Bottcher, C. J. F., and F. P. Woodford. 1962. Chemical changes in the arterial wall associated with atherosclerosis. Fed. Proc. 21.(4, P.t. 1) : 15-19.

21. Bhattacharyya, A. K., W. E. Connor, F. A. Mausolf, and A. E. Flatt. 1972. Xanthoma cholesterol turnover in hyperlipoproteinemic patients. Circulation. 46: 250. (Abstr.)

22. Wahlqvist, M. L., A. J. Day, and R. K. Tume. 1969. Incorporation of oleic acid into lipid by foam cells in human atherosclerotic lesions. Circ. Res. 24: 123-130.

23. Frantz, I. D., J. B. Carey, R. Moss, J. F. Eckert, M. Goldfarb, and H. I. Katz. 1958. Observations on the turnover of cholesterol in a human subject. Minn. Med. $41: 157$.

24. Lofland, H. B., and T. B. Clarkson. 1970. The bi-directional transfer of cholesterol in normal aorta, fatty streaks, and atheromatous plaques. Proc. Soc. Exp. Biol. Med. 133: 1-8.

25. Zilversmit, D. B. 1960 . The design and analysis of isotope experiments. Am. J. Med. 29: 832-848. 